\title{
Hemşirelerin Kanser Hastalarına Yönelik Manevi Bakım Uygulamaları ve Karşılaştıkları Engeller
}

\author{
Nurses' Spiritual Care Practices and Barriers for Cancer Patients \\ Fatma USLU ŞAHAN ${ }^{1}$, Füsun TERZİOĞLU²
}

\section{ÖZ}

Kanser gibi yaşamı tehdit eden hastalığa sahip bireylerde manevi gereksinimler soyut ve karmaşık olup ölçümü güçtür. Bu nedenle kanser hastalarında ölçümü daha kolay olan fiziksel gereksinimler öncelikle ele alınmakta, manevi gereksinimler gözden kaçabilmektedir. Araştırmada, kanser hastası ile en fazla zaman geçiren sağlık profesyonellerinden hemşirelerin manevi bakım ve uygulamaları ile manevi bakım hizmeti sunarken karşılaşabilecekleri engeller konusunda görüşlerinin belirlenmesi amaçlanmıştır.

Tanımlayıcı tipteki araştırmanın örneklemini bir üniversite hastanesinin onkoloji kliniklerinde çalışan 134 hemşire oluşturmuştur. Araştırmanın verileri yarı yapılandırılmış anket formu kullanılarak toplanmıştır.

Hemşirelerin, \%69,4'ünün kendilerini manevi açıdan oldukça güçlü olarak tanımladıkları, \%50,7'sinin hastalarına bazen manevi bakim uyguladıkları, \%81,3’ünün, manevi bakım konusunda eğitim almadıkları saptanmıştır. Hemşireler manevi bakımda "hastalar için önemli olan manevi aktivitelerin ve inanışların desteklenmesi $(\% 68,6)$ " nin hastalar için çoğu zaman uygun bir uygulama olduğunu belirtmişlerdir. Hemşireler manevi bakımda karşılaşılan en önemli engelleri; "yeterli zaman yokluğu $(\% 94,8)$ ", "hasta ile manevi konuların konuşulup tartışılabileceği özel mekanların yokluğu $(\% 89,5) "$ ve "manevi konularda eğitim eksikliği $(\% 83,6)$ " olarak belirtmişlerdir.

Onkoloji hemşirelerin mezuniyet sonrası eğitimler ile manevi bakım konusunda bilgi düzeylerinin iyileştirilmesi; manevi bakımın sadece teorik eğitim ile kalmaması, hastaların gereksinimleri doğrultusunda manevi bakım uygulamalarının sıklığının arttırılması önerilmektedir.

Anahtar Kelimeler: Hemşirelik bakımı, Kanser, Manevi Bakım, Onkoloji Hemşireliği.

\begin{abstract}
Spiritual needs are intangible and complex and difficult to measure in individuals with lifethreatening diseases such as cancer. For this reason, physical needs, which are easier to measure in cancer patients, are primarily addressed and spiritual needs can be overlooked. The aim of the study was to determine the views of nurses, who spend the most time with cancer patients, who care for cancer patients about the spiritual care and practices and the barriers they may encounter while providing spiritual care.
\end{abstract}

The sample of this descriptive study consisted of 134 nurses working in the oncology clinics of a university hospital. A semi-structured questionnaire were used for data collection.

It was found that $69.4 \%$ of nurses described themselves as highly spiritual, $50.7 \%$ of them sometimes applied spiritual care to their patients, $81.3 \%$ of the nurses did not receive training in spiritual care. The majority of nurses stated that "supporting spiritual activities and beliefs that are important for patients $(68.6 \%)$ " in spiritual care are often appropriate for patients. Nurses indicated the most important obstacles encountered in spiritual care as "lack of sufficient time (94.8\%)", "the absence of special places to discuss and discuss spiritual issues with the patient $(89.5 \%)$ " and "lack of education in spiritual subjects $(83.6 \%)$ ".

It is recommended to improve oncology nurses' level of knowledge about spiritual care through postgraduate training; to increase the frequency of spiritual care practices in line with the needs of the patients, not only with the theoretical education of spiritual care.

Keywords: Cancer, Spiritual Care, Nursing Care, Oncology Nursing.

\footnotetext{
1 Dr. Öğr. Üyesi Fatma USLU ŞAHAN, Doğum ve Kadın Hastalıkları Hemşireliği, Hacettepe Üniversitesi Hemşirelik Fakültesi, fatma.uslu@ hacettepe.edu.tr, ORCID: 0000-0001-6451-296X

2 Prof. Dr. Füsun TERZİOĞLU, Doğum ve Kadın Hastalıkları Hemșireliği, Atılım Üniversitesi Sağlık Bilimleri Fakültesi, fusun.terzioglu@atilim.edu.tr, ORCID: 0000-0002-8457-0048 


\section{GíRiş}

Maneviyat bireyin yaşamın anlamını, evrendeki yerini, kendisi ve diğer insanlarla ilişkilerini anlama çabası olarak tanımlanmakta; inançlar, değerler, gelenekler ve uygulamalar ile ifade edilmektedir. ${ }^{1}$ Erişen ve ark.'nın aktardığına göre manevi bakım ise "sıkıntıll, korku dolu dönemlerinde, aniden gelen (hastalık, ameliyat, sakatlik vb.) kriz durumlarında, onların yanında olmak, onlara inanç ve din desteği sağlamak, varsa soru ve sorunlarının çözümünde etkili olabilmek, adet ve ibadetlerini yerine getirebilmede yol göstermek, var oluşlarına ve hayatlarına yeni bir anlam verebilmede yardımc1 olmaktır". Kanser gibi yaşamı tehdit eden hastalıklar; bireylerin fiziksel, ruhsal, duygusal ve sosyal ihtiyaçları ile birlikte manevi ihtiyaçlarını da arttırmaktadır. ${ }^{1,4-8}$ Amerika Klinik Onkoloji Derneği [American Societyof Clinical Oncology $^{9}$ ve Uluslararası Birleşik Komisyon'u (Joint Commission International) $^{10}$ kanser hastalarına sunulan manevi bakımı, temel bir bakım unsuru olarak belirtmekte ve sağlik profesyonellerinin bu alanda eğitim alması gerektiğini vurgulamaktadır. Literatürde, sağlık ekibinin manevi desteği ve hastaların yaşam kalitesi arasında anlamlı ilişkiler olduğu, ${ }^{3,5,11-13}$ manevi bakımın yaşam sonunda hastalara uygulanan gereksiz tedavileri azalttığ ${ }^{3,5}$ ve buna bağlı olarak maliyeti düşürdüğü belirtilmektedir. ${ }^{5}$ Ayrıca, hastaların manevi gereksinimlerin giderilmesinin hastalıkları ile baș etmede önemli rol oynadı $\breve{g}_{1}, 1,12,14$ hastalıklarına uyumu kolaylaştırdı $\breve{g}_{1},{ }^{12}$ ağr1 ${ }^{15}$ ve anksiyetesini $^{12,14,15}$ azalttığı saptanmıştır. Narayanasamy and Owens hastalara uygulanan manevi bakım girişimlerinin doğrudan ya da dolaylı olarak stresi azalttığını, hastalık ve ağrı ile baş edebilmek için duygusal güç kazandırdığını belirtmektedir. ${ }^{14}$ Kanser hastalarının manevi gereksinimlerine yönelik yapılan uygulamalar bakımın ayrılmaz bir tamamlayıc1sı olabilmektedir.

Manevi bakım, hastalıklarının manevi yönünün tanınmasını ve hastaların manevi ihtiyaçlarının giderilmesini sağlamaktadır. ${ }^{1,4,5,11,16}$ Yurt dışında manevi danışmanlık din görevlileri (papaz, rahip gibi) tarafindan sunulan sosyal hizmettir. ${ }^{17}$ Türkiye'de 07.01.2015 tarihinde Diyanet İşleri Başkanlığı ile Sağlı Bakanlığı arasında "Sağlık Tesislerinde Manevi Destek Sunmaya Yönelik İşbirliği Protokolü" imzalanmış ve Diyanet İşleri Başkanlığı tarafından, belirlenen kişilere eğitim verilmeye başlanmıştır. $^{18}$ Protokol kapsamında 2015 yılı içinde bazı pilot illerde (Ankara, Erzurum, İstanbul, Kayseri, Samsun ve Ordu), 2016 y1lindan itibaren ise pilot illere ek olarak 14 ilde manevi bakım uzmanları aracılığı ile manevi destek hizmeti sunulmaya başlanmıştır. Manevi bakım uzmanlarından, hastalara din ve hayat görüşlerine dayalı olarak profesyonel destek sağlaması, hastaların hastalığı ya da problemi ile ilişkili olumsuz dini düşünceleri olumluya dönüștürmesine yardımcı olması beklenmektedir. ${ }^{19}$ Ancak, Phelps ve arkadaşları, ${ }^{17}$ hastaların oldukça önemli bir kısmının (\%41-94) manevi bakımı hekim ve hemşirelerden aldıklarını belirtmektedir. Kanser hastalarına yönelik hazırlanan rehberlerde manevi bakımın mesleklerarası ekip tarafından sağlanması tavsiye edilirken, hastaların manevi bakım ihtiyacının belirlenmesinde hemşirenin önemini vurgulamaktadır. ${ }^{20,21}$

Literatürde yer alan bazı çalışmalar ise hemşirelerin manevi bakımı ihmal ettiğini $^{3,5,11,14,24}$ ve hastaların manevi gereksinimlerinin yeterli düzeyde

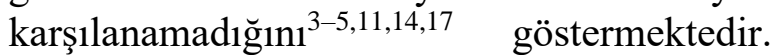
Pearce ve arkadaşları kanser hastaları ile yaptıkları çalışmalarında, hastaların tamamına yakınının (\%91) manevi ihtiyaçları olduğunu saptamış ve sağlık profesyonellerinin hastalarının manevi ihtiyaçlarını sınırlı oranda karşıladığını (\%17) bildirilmişlerdir. ${ }^{4} \quad$ Yaşam sonu bakımda, maneviyatın önemini belirlemek amacıyla; kanser hastaları, onkoloji hemşire ve doktorları ile yapılan bir başka çalışmada ise, hastaların \% 77,9'u, hemşirelerin \%85, 1'i ve hekimlerin \%71,6's1 hastalara sağlanan 
sürekli manevi bakım hizmetinin hasta üzerinde olumlu etkileri olacağ 1 belirtilmiş ancak hastaların sadece \%25'inin daha önce manevi bakım aldığ 1 saptanmıştır. ${ }^{17}$ Ancak maneviyatın bireyin sağlı̆̆ını etkileyebileceği, manevi ihtiyaçların karşılanmadığ 1 durumlarda bireyde fizyolojik ve psikolojik rahatsızlıklara neden olabileceği hem tıp hem de hemşirelik tarafindan kabul edilmektedir. Manevi gereksinimlerin, fiziksel gereksinimlere göre daha karmaşık ve soyut olmasından dolayı, ölçümü de güç olabilmektedir. ${ }^{15,16,25} \mathrm{Bu}$ nedenden dolayı bireyin bakımında kolaylıkla ölçülebilen ve daha açık olan fiziksel gereksinimler öncelikle ele alınmakta, manevi gereksinimler gözden kaçabilmektedir. ${ }^{16,25}$ Öncelikle maneviyatın hemşireler tarafindan nasıl ifade edildiği konusu aydinlatılmalıdır. $\mathrm{Bu}$ nedenle çalışmamızda, kanser hastası ile en fazla zaman geçiren hemşirelerin manevi bakım ve uygulamaları ile manevi bakım hizmeti sunarken karşılaşabilecekleri engeller konusunda görüşlerinin belirlenmesi amaçlanmıştır.

\section{MATERYAL VE METOT}

\section{Araştırmanın Tipi}

Araştırma kesitsel ve tanımlayıcı tipte yapılmıştır.

\section{Araştırmanın Evreni ve Örneklemi}

Araştırmanın evrenini, Ankara il merkezinde bir üniversite hastanesinin onkoloji kliniklerinde çalışan 183 hemşire oluşturmuştur. Araştırmada örneklem seçimine gidilmemiş, evrenin tamamına ulaşılması hedeflenmiştir. Araştırmaya dâhil olma kriterleri; araştırmaya katılmayı kabul etme ve en az bir yıldır onkoloji hastasina bakım verme olarak belirlenmiştir. Araştırmaya katılmayı kabul etmeyen ve araştırma sürecinde görev yaptığı klinikte bulunmayan 11 hemşire (altı kişi doğum sonu izinde, beş kişi raporlu) araştırmaya dâhil edilmemiștir. Araștırma, örneklem seçim kriterlerini karşılayan 134 hemşire (\%73) ile gerçekleştirilmiştir.

\section{Verilerin Toplanması}

Araştırmanın verileri, Ekim 2015-Şubat 2016 tarihleri arasında araştırmacılar tarafindan yüz yüze görüşme yöntemi kullanılarak toplanmıştır. Araştırmada kullanılan veri toplama formlarının doldurulması 10-15 dakika sürmüştür. Araştırmada verileri yarı yapılandırılmış anket formu aracılığı ile toplanmıştır.

\section{Yarı Yapılandırıımış Anket Formu}

Araştırmacılar tarafından ilgili literatür ${ }^{5,14-}$ 17,25,26 taranarak oluşturulan bu form iki bölümden oluşmaktadır. Formun birinci bölümü hemşirelerin; cinsiyetini, çalışma yılını, çalıştıkları onkoloji bölümünü, kendini maneviyatı güçlü biri olarak tanımlama düzeyini, bakım verilen hastaların ileri evre kanser hastas1 olma oranını, manevi inanışlarının tıbbi uygulamaları etkileme durumunu belirlemeye yönelik yedi sorudan oluşmaktadır. Formun ikinci bölümü; hemşirelerin manevi bakım ve manevi bakım uzmanı konusunda bilgi ve görüşlerini belirlemeye yönelik yedi sorudan, hemşirelerin bazı manevi bakım uygulamalarının hastaları için uygunluk durumunu belirlemeye yönelik sekiz ifadeden ve hemşirelerin manevi bakımda karşılaşılan engellerin önem derecesini belirlemeye yönelik 13 ifadeden oluşmaktadır.

Araştırma uygulamasına başlamadan önce sekiz hemşire ile ön uygulama yapılmıştır. Ön uygulama sonrası anket formunda bir değişiklik yapılmamış ve ön uygulamaya katılan hemşireler araştırma kapsamına dâhil edilmemiştir.

\section{Verilerin Analizi}

Verilerin analizi için SPSS 20.0 istatistik programı kullanılmıştır. Araştırmadan elde edilen bulgular sayı ve yüzde belirtilerek sunulmuştur.

\section{Araștırmanın Etik Yönü}

Araştırmanın yürütülebilmesi için bir üniversitenin girişimsel olmayan etik kurulundan tarih:16.09.2015) (say1:16969557-1074; 
gerçekleştirildiği hastaneden yazılı izin (say1:27043162-020/2435; tarih:28.09.2015) alınmıştır. Araştırma kapsamına alınan hemşirelere araştırmanın amacı hakkında bilgi verilmiş, araştırmaya katılmayı kabul edenlerden yazılı onamları alınmıştır.

\section{Araş̧tırmanın Sınırlılığı}

$\mathrm{Bu}$ araştırma, bir üniversite hastanesinin onkoloji kliniklerinde çalışan hemşireleri kapsamakta olup araştırmadan elde edilen sonuçlar tüm onkoloji hemşirelerine genellenemez. Araştırmanın sonuçları, araştırmaya katılan hemşirelerin bildirimine dayalidir.

\section{BULGULAR VE TARTIŞMA}

Araștırmaya katılan hemşirelerin \%95,5'inin kadın olduğu, \%41,7'sinin 6-10 yıldır çalıştığı ve \%54,4'ünün tıbbi onkoloji bölümünde çalıştıkları belirlenmiştir. Hemşirelerin \%69,4'ü kendilerini manevi açıdan oldukça kuvvetli olarak tanımladıkları saptanmıștır. Hemşireler $(\% 64,2)$ bakım verdikleri hastaların \%10-\%70'inin ileri evre kanser hastası olduğunu belirtmiştir. Hemşirelerin \%58,2'si manevi inanışlarının tedavi uygulamalarını etkilemediğini belirtmişlerdir (Tablo 1).

Tablo 1. Tanıtıcı Özellikler ( $\mathrm{N}=134)$

\begin{tabular}{|c|c|c|}
\hline Tanıtıcı Özellikler & Sayı & $\%$ \\
\hline \multicolumn{3}{|l|}{ Cinsiyet } \\
\hline Erkek & 6 & 4,5 \\
\hline Kadın & 128 & 95,5 \\
\hline \multicolumn{3}{|l|}{ Çalışma Yılı } \\
\hline $1-5$ & 53 & 39,6 \\
\hline $6-10$ & 56 & 41,7 \\
\hline$>11$ & 25 & 18,7 \\
\hline \multicolumn{3}{|l|}{ Çalışılan Onkoloji Bölümü } \\
\hline Tibbi & 73 & 54,4 \\
\hline Tibbi+Palyatif & 31 & 23,1 \\
\hline Tibbi+Palyatif + Pediatri & 11 & 8,2 \\
\hline Palyatif Bakım & 7 & 5,2 \\
\hline Diğer (Tibbi/Radyasyon / & 12 & 9,1 \\
\hline Palyatif Bakım+ Pediatri) & & \\
\hline \multicolumn{3}{|c|}{$\begin{array}{l}\text { Kendini maneviyatı güçlü biri olarak tanımlama } \\
\text { durumu }\end{array}$} \\
\hline Oldukça & 93 & 69,4 \\
\hline Kismen & 38 & 28,4 \\
\hline Hiç & 3 & 2,2 \\
\hline \multicolumn{3}{|c|}{$\begin{array}{l}\text { Bakım verilen hastaların ileri evre kanser hastası } \\
\text { olma oranı }\end{array}$} \\
\hline$<\% 10$ & 23 & 17,1 \\
\hline$\% 10-\% 70$ & 86 & 64,2 \\
\hline$\%>70$ & 25 & 18,7 \\
\hline \multicolumn{3}{|c|}{$\begin{array}{l}\text { Manevi inanışların tedavi uygulamalarını etkileme } \\
\text { durumu }\end{array}$} \\
\hline Etkiler & 31 & 23,2 \\
\hline Kararsızım & 25 & 18,6 \\
\hline Etkilemez & 78 & 58,2 \\
\hline
\end{tabular}

Araștırmaya katılan hemşirelerin çoğunluğu manevi iyilik halinin hastanın yaşam kalitesine oldukça etki ettiğini $(\% 79,1)$, hastalarına bazen manevi bakım uygulayabildiklerini $(\% 50,7)$ belirtmişlerdir. Hemşirelerin \%81,3'ünün manevi bakım konusunda eğitim almadığı, \%83,3'ünün manevi bakım konusunda kurs açılmasını istediği, \% 59,7'sinin profesyonel manevi bakım uzmanı konusunda bilgi sahibi olmadığı, \%73,1'inin çalıştıkları kurumda manevi bakım uzmanı olmadığını, \%77,6'sının ekip içerisine manevi bakım uzmanının dahil olmasını istediği belirlenmiştir (Tablo 2).

Araştırmada hemşireler çoğunluğu manevi bakımda "hastalar için önemli olan manevi aktivitelerin ve inanışların desteklenmesi $(\% 68,6)$ "nin ve "manevi konularda konuşmak isteyen hastalara din görevlisi ile konuşmak isteyip istemediklerinin sorulması $(\% 50,8)$ "nın ve "hastalar manevi desteğe sahip ise desteği sağlayacak kişilerin tedaviye dahil olmasinı isteyip istemediklerinin sorulması $(\% 50,7)$ 'nın hastalar için çoğu zaman uygun bir uygulama olduğunu belirtmişlerdir. "Manevi duyguları yüksek hastaya dua etmesi için din görevlisi önerilmesi (\%50,7)" manevi bakım uygulamasına hemşirelerin \%50,7'si bazen uygun bir uygulama olabileceğini belirtirken \%23,9'u hastalar için hiç uygun bir uygulama olmadığını belirtmiştir. 
Tablo 2. Manevi Bakım ve Manevi Bakım Uzmanı Konusunda Bilgi ve Görüşler (N=134)

\begin{tabular}{|c|c|c|}
\hline Ifadeler & Sayı & $\%$ \\
\hline \multicolumn{3}{|c|}{$\begin{array}{l}\text { Manevi iyilik halinin hastanın yaşam kalitesine } \\
\text { etkisi }\end{array}$} \\
\hline Hiç etkili değil & 2 & 1,5 \\
\hline Kismen & 26 & 19,4 \\
\hline Oldukça & 106 & 79,1 \\
\hline \multicolumn{3}{|l|}{ Manevi bakım uygulama sıklığı } \\
\hline Hiçbir zaman & 2 & 1,5 \\
\hline Bazen & 68 & 50,7 \\
\hline Çoğu zaman & 64 & 47,8 \\
\hline \multicolumn{3}{|c|}{ Manevi Bakım ile ilgili eğitim alma } \\
\hline Evet & 25 & 18,7 \\
\hline Hayır & 109 & 81,3 \\
\hline \multicolumn{3}{|c|}{ Manevi bakım konusunda kurs açılmasını isteme } \\
\hline Evet & 112 & 83,6 \\
\hline Hayır & 22 & 16,4 \\
\hline \multicolumn{3}{|c|}{ Profesyonel Manevi Bakım Uzmanı hakkında bilgi } \\
\hline Bilgim yok. & 80 & 59,7 \\
\hline $\begin{array}{l}\text { Evet, ülkemde bu kişilere } \\
\text { çalışma ortamında karşılaştım. }\end{array}$ & 24 & 17,9 \\
\hline $\begin{array}{l}\text { Evet, yurt dışında bulunduğum } \\
\text { sırada bu kişiler ile karşılaştım. }\end{array}$ & 4 & 3,0 \\
\hline $\begin{array}{l}\text { Evet, profesyonel literatüre } \\
\text { göre bu kişilerin varlığını } \\
\text { biliyorum. }\end{array}$ & 26 & 19,4 \\
\hline \multicolumn{3}{|c|}{ Çalışılan kurumda manevi bakım uzmanı varlığı } \\
\hline Evet & 36 & 26.9 \\
\hline Hayır & 98 & 73.1 \\
\hline \multicolumn{3}{|c|}{$\begin{array}{l}\text { Ekibe manevi bakım uzmanının dâhil olmasını } \\
\text { isteme }\end{array}$} \\
\hline Hayır & 2 & 1,5 \\
\hline Belki & 28 & 20,9 \\
\hline Evet & 104 & 77,6 \\
\hline
\end{tabular}

"Hasta birlikte dua edilmesini isterse, doktor ya da hemşirenin hasta ile birlikte dua etmesi" manevi bakım uygulamasina hemşirelerin \%43,3'ü bazen uygun bir uygulama olabileceğini belirtirken, $\% 40,3$ 'ü hastalar için hiç uygun bir uygulama olmadı ğını belirtmiş̧tir (Tablo 3).

Araştırmada hemşireler manevi bakımda karşılaşılan "yeterli zaman yokluğu $(\% 94,8)$ ", "hasta ile manevi konularm konuşulup tartışılabileceği özel mekanların yokluğu $(\% 89,5)$ " ve "manevi konularda eğitim eksikliği $(\% 83,6) "$ engellerinin oldukça önemli engeller olduğunu belirtmişlerdir.

Bununla birlikte, hemşireler "hasta ile hemşire arasındaki güç dengesizliği nedeniyle hemşirelerin manevi destek sağlamalarının uygun olmayacağını düşünmesi (\%46,3)", "manevi desteğin hastanın ailevi dinamiklerini bozacağının düşünülmesi $(\% 41,8)$ " ve "hemşirelerin kendilerininkinden farklı manevi inançları olan hastalar ile ilişki kurmada rahatsızlık hissetmesi (\%37,3)" engellerinin karşılaşılan engeller arasında az önemli engellerden olduğunu belirtmişlerdir.

Manevi bakımda karşılaşılan "Hemşireler

Tablo 3. Manevi Bakım Uygulamalarına Yönelik Görüşler (N=134)

\begin{tabular}{|c|c|c|c|c|c|c|}
\hline \multirow[t]{2}{*}{ İfadeler } & \multicolumn{2}{|c|}{$\begin{array}{l}\text { Hiç Uygun } \\
\text { Değil }\end{array}$} & \multicolumn{2}{|c|}{ Bazen Uygun } & \multicolumn{2}{|c|}{$\begin{array}{l}\text { Çoğu Zaman } \\
\text { Uygun }\end{array}$} \\
\hline & Sayı & $\%$ & Sayı & $\%$ & Sayı & $\%$ \\
\hline $\begin{array}{l}\text { Hastaların manevi geçmişi ile ilgili sorular sorarak bu konuların } \\
\text { onlar için önemli olup olmadığının belirlenmesi }\end{array}$ & 25 & 18,7 & 57 & 42,5 & 52 & 38,8 \\
\hline $\begin{array}{l}\text { Hastalar için önemli olan manevi aktivitelerinin ve inanışların } \\
\text { desteklenmesi }\end{array}$ & 5 & 3,7 & 37 & 27,7 & 92 & 68,6 \\
\hline $\begin{array}{l}\text { Hastalar isterse, manevi konularda sorular sorulması ve bu } \\
\text { konularda konuşulması }\end{array}$ & 22 & 16,4 & 48 & 35,8 & 64 & 47,8 \\
\hline $\begin{array}{l}\text { Maneviyatı güçlü hastalar için tedavi kararlarında inançlarının } \\
\text { etkili olup olmadığının sorgulanması }\end{array}$ & 14 & 10,4 & 56 & 41,8 & 64 & 47,8 \\
\hline $\begin{array}{l}\text { Manevi konularda konuşmak isteyen hastalara din görevlisi ile } \\
\text { konuşmak isteyip istemediklerinin sorulması }\end{array}$ & 7 & 5,2 & 59 & 44 & 68 & 50,8 \\
\hline $\begin{array}{l}\text { Hastalar manevi desteğe sahip ise desteği sağlayacak kişilerin } \\
\text { tedaviye dahil olmasını isteyip istemediklerinin sorulması }\end{array}$ & 12 & 9 & 54 & 40,3 & 68 & 50,7 \\
\hline $\begin{array}{l}\text { Hasta birlikte dua edilmesini isterse doktor ya da hemşirenin } \\
\text { hasta ile birlikte dua etmesi }\end{array}$ & 54 & 40,3 & 58 & 43,3 & 22 & 16,4 \\
\hline $\begin{array}{l}\text { Manevi duyguları yüksek hastaya dua etmesi için din görevlisi } \\
\text { önerilmesi }\end{array}$ & 32 & 23,9 & 68 & 50,7 & 34 & 25,4 \\
\hline
\end{tabular}


kendilerininkinden farklı manevi inançları olan hastalar ile manevi konularda konuşurken rahatsızlık hissetmesi $(\% 44,8)$ " engelinin önemli bir engel olmadığını belirtmişlerdir (Tablo 4).

Tablo 4. Manevi Bakımda Karşıllaşılan Engellere Yönelik Görüşler (N=134)

\begin{tabular}{|c|c|c|c|c|c|c|}
\hline \multirow[t]{2}{*}{ Engeller } & \multicolumn{2}{|c|}{$\begin{array}{l}\text { Önemli } \\
\text { Değil }\end{array}$} & \multicolumn{2}{|c|}{ Az Önemli } & \multicolumn{2}{|c|}{$\begin{array}{l}\text { Oldukça } \\
\text { Önemli }\end{array}$} \\
\hline & Sayı & $\%$ & Sayı & $\%$ & Sayı & $\%$ \\
\hline Yeterli zaman yokluğu & 3 & 2,2 & 4 & 3 & 27 & 94,8 \\
\hline $\begin{array}{l}\text { Hasta ile manevi konuların konuşup tartışabileceği özel mekanların } \\
\text { yokluğu }\end{array}$ & 1 & 0,8 & 13 & 9,7 & 20 & 89,5 \\
\hline Manevi konularda bireysel eğitimin olmaması & 8 & 6 & 14 & 10,4 & 12 & 83,6 \\
\hline Manevi konularda konuşurken rahatsız olma & 22 & 16,4 & 38 & 28,4 & 74 & 55,2 \\
\hline Bireysel olarak maneviyatın önemli olmaması & 52 & 38,8 & 30 & 22,4 & 52 & 38,8 \\
\hline $\begin{array}{l}\text { Manevi desteğin tedavi ekibinde yer alan başka profesyoneller } \\
\text { tarafından daha iyi verileceğine inanma }\end{array}$ & 12 & 9 & 32 & 23,8 & 90 & 67,2 \\
\hline $\begin{array}{l}\text { Kanser hastalarının manevi destek almak istemediklerinin } \\
\text { düşünülmesi }\end{array}$ & 28 & 20,9 & 45 & 33,6 & 61 & 45,5 \\
\hline $\begin{array}{l}\text { Hastaların manevi destek alırken } \quad \text { kendilerini } \\
\text { hissetmeyeceklerinin düşünülmesi }\end{array}$ & 13 & 9,7 & 52 & 38,8 & 69 & 51,5 \\
\hline $\begin{array}{l}\text { Hasta ile hemşire arasındaki güç dengesizliği nedeniyle hemşirelerin } \\
\text { manevi destek sağlamalarının uygun olmayacağını düşünmesi }\end{array}$ & 26 & 19,4 & 62 & 46,3 & 46 & 34,3 \\
\hline $\begin{array}{l}\text { Hemşirelerin kendilerininkinden farklı manevi inançları olan hastalar } \\
\text { ile manevi konularda konuşurken rahatsılık hissetmesi }\end{array}$ & 60 & 44,8 & 31 & 23,1 & 43 & 32,1 \\
\hline $\begin{array}{l}\text { Hastalar ile manevi bağlantı kurmanın hemşireliğin profesyonel } \\
\text { rolleri ile ilişkili olmadığının düşünülmesi }\end{array}$ & 32 & 23,9 & 44 & 32,8 & 58 & 43,3 \\
\hline $\begin{array}{l}\text { Manevi desteğin hastanın ailevi dinamiklerini bozacağının } \\
\text { düşünülmesi }\end{array}$ & 40 & 29,9 & 56 & 41,8 & 38 & 28,3 \\
\hline $\begin{array}{l}\text { Hemşirelerin kendilerininkinden farklı manevi inançları olan hastalar } \\
\text { ile ilişki kurmada rahatsılık hissetmesi }\end{array}$ & 43 & 32,1 & 50 & 37,3 & 41 & 30,6 \\
\hline
\end{tabular}

Kanser gibi yaşamı tehdit eden hastalıklar yoğun tedavi süreci nedeniyle hasta ve ailesi tarafından önemli bir stres kaynağı olarak algılanabilmekte ve manevi sorunları ortaya ç1karabilmektedir. ${ }^{1,6,7,11,27} \mathrm{Bu}$ nedenle, hastaların varoluşunun tüm boyutlarını sürdürmesinde ve korumasında ona yardımc1 olmak iyi hemşirelik bakımının temelinde yer almaktadır. ${ }^{15}$ Ancak, hemşirelerin bakım verdikleri hastaların manevi bakımı sağlayabilmeleri için kendi maneviyatının farkında olması ve manevi iyilik halini arttırmaya yönelik stratejiler geliştirmesi gerekmektedir. ${ }^{15,16}$ Araştırmada hemşirelerin \%69,4'ünün kendilerini manevi açıdan oldukça kuvvetli olarak tanımladıkları saptanmıştır. Literatürde terminal dönemdeki kanser hastalarına bakım sağlayan hemşirelerin kendilerini manevi açıdan orta derecede kuvvetli olarak tanımladıkları belirtilmektedir. ${ }^{3,17,26}$ Ayrıca araştırmada, hemşirelerin \%58,2'si manevi inanışlarının tedavi uygulamalarını etkilemediğini belirtmişlerdir. Hemşirelerin kendi manevi düşüncelerinden etkilenmeden destekleyici manevi bakım hizmeti sunabilmesi bütüncül sağlık bakımı açısından oldukça önemlidir. ${ }^{16,28,29}$ Hemșirelerin manevi bakımı ve gereksinimleri algılaması, kendi yaşam umudu, konuya duyarlılığı ve maneviyatı nasıl anlamlandırdığını değerlendirmesi, hastalara sunulan manevi bakım kalitesinin arttırılmasında etkili olabilmektedir.

Literatürde manevi iyilik halinin hastanın yaşam kalitesi üzerine olumlu etkisi

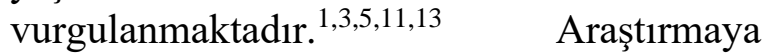
katılan hemşirelerin çoğunluğu manevi iyilik halinin hastanın yaşam kalitesine oldukça olumlu etki ettiğini $(\% 79,1)$ belirtmişlerdir. Balboni ve ark. manevi bakımın kanser bakımı üzerine olumlu etkileri olduğunu belirterek kanser bakımının ayrılmaz bir parçası olduğunu vurgulamışlardır. ${ }^{3}$ BarSela ve ark. hekim ve hemşirelerin manevi 
bakım verdikleri son hastayı düşünmeleri istenerek uygulanan bakımın hastayı nasıl etkilediğini öğrenmeyi amaçladıkları çalıșmalarında, katılımcıların \%50'si hastaları oldukça olumlu etkilediğini belirtmiştir. $^{6}$ Manevi bakımın hastanın yaşam kalitesini etkilemede ve tedavi sürecini şekillendirmede oynayabileceği rol göz önüne alındığında, sunulan bakımın rutin bir parçası olması önerilmektedir.

Manevi bakım bütüncül bakım içerisinde temel insan gereksinimi olarak değerlendirilmektedir. Ancak manevi bakımına uygulamada yeterli önemin verilmediği görülmektedir. ${ }^{3-5,28,30}$ Araştırmada hemşireler hastalarına bazen manevi bakım uyguladıklarını (\%50,7) belirtmişlerdir. Balboni ve ark. çalışmasında, kanser hastalarına bakım veren hemşirelerin \%87'sinin manevi bakımı kanser hastalarının bakım sürecine bazen dahil ettikleri belirlenmiş, hemşirelerin \%58'i manevi bakımı kanser bakımının önemli bir parçası olduğunu vurgulamıștır. $^{3}$ Bar-Sela ve ark. çalışmasında hekim ve hemşirelerin \%47'nin ileri evre kanser hastalarına manevi bakım uyguladıkları belirlenmiştir. ${ }^{6}$ BarSela ve ark. Türkiye'nin de içinde bulunduğu Orta Doğu Kanser Konsorsiyumu'na [Middle East Cancer Consortium (MECC)] üye 14 ülkeden hekim ve hemşireleri dahil ettikleri çalışmasında hekim ve hemşirelerin \%28's1 sik s1k, \%32'si her zaman hastalarına manevi bakım uyguladıkları belirlenmiştir. ${ }^{7}$ Johnston Taylor ve ark. hemşirelerin 72-80 saat içerisinde hastalarına manevi bakım sağlama sıklığını belirlemeyi amaçladıkları çalışmalarında, hemşirelerin oldukça seyrek manevi bakım uyguladıklarını belirlenmiş ve hemşirelerin manevi bakım uygulayabilmeleri için bu konuda eğitime ve desteğe ihtiyaçları olduğunu vurgulamışlardır. ${ }^{30} \quad$ Araştırmamızda, hemşirelerin yarısının bazen manevi bakım uyguladığını belirtmesinin bu konuda yeterli bilgiye sahip olmadıklarından kaynaklandığı düşünülebilir. Hemşirelerin manevi bakım verebilmesi için, temel hemşirelik teorik ve pratik eğitiminde manevi bakıma yeterli yer verilmesi önerilmektedir.

Hemşireliğin manevi iyilik hali üzerindeki potansiyel etkisinin bilinmesine rağmen, bütüncül hemşirelik bakımının manevi boyutu hemşirelik eğitimi içinde ihmal edilmiş bir alan olarak karşımıza çıkmaktadır. ${ }^{16,28,30,31}$ Yapılan çalışmalarda, hemşirelerin çoğunluğu manevi bakım sağlamayı profesyonel rollerinin bir parçası olarak düşünmemekte ${ }^{32}$ veya bu rolü onlardan daha iyi yerine getirebilecek kişilerin olduğuna inanmakta ${ }^{1,26,33}$ oldukları belirlenmiştir. $\mathrm{Bu}$ sonuç, hemşirelerin manevi bakım konusunda yeterli eğitim almamalarına, bilgi ve beceri eksikliğine veya hastaları ile konuşmak için kendilerini hazır hissetmemeleriyle ilişki olabilir. ${ }^{8}$ Araştırmaya katılan hemşirelerin \%81,3'ü manevi bakım konusunda eğitim almadığını, \%83,3'ü manevi bakım konusunda kurs açılmasını istediğini belirtmiştir. Literatürde, hekim ve hemşirelerin \%88'inin manevi bakım konusunda eğitim almadığı, \%77'sinin profesyonel manevi bakim konusunda eğitim almak istedikleri vurgulanmaktadır. ${ }^{3,6}$ Balboni ve ark. terminal dönem kanser hastalarına manevi bakım sunumuna etki eden faktörleri belirlemeyi amaçladıkları çalışmalarında hekim ve hemşirelerin manevi bakım konusunda eğitim sahibi olmasının manevi bakım hizmeti sunumunda önemli bir belirleyici olduğu saptanmıştır. Ayrıca araştırmada hemşirelerin \%59,7'si profesyonel manevi bakım uzmanı konusunda bilgi sahibi olmadığını, \%73,1'i çalıştıkları kurumda manevi bakım uzmanı bulunmadığını, \%77,6'sı ekip içerisine manevi bakım uzmanının dahil olmasını istedikleri ortaya konulmuştur. ${ }^{3}$ Bar-Sela ve ark. çalışmasında da benzer sonuçlar belirtilmiş, hekim ve hemşirelerin \%54'ünün daha önce profesyonel manevi bakim uzmanına aşina oldukları, \%74'ünün çalıştıkları kurumda manevi bakım uzmanı olmadığını ve \%68'inin bakım ekibine manevi bakım uzmanını dahil edilebileceği belirlenmiştir. ${ }^{6}$ 
Manevi bakım, hemşirelik bakımının ayrı bir yönü olarak düşünülmemeli, bütüncül bakımın bir parçası olarak değerlendirilmelidir. ${ }^{1,3,4,15} \quad$ Literatürde manevi bakım uygulamalarında hemşirelerin uygulaması gereken girişimler belirtilmiş, ${ }^{1,20,21,27,28}$ hastaların manevi iyilik halinin arttırılabilmesi için, hastaların manevi ihtiyaçlarının değerlendirilmesi, manevi hemşirelik tanılarının belirlenmesi, güçlü bir hasta-hemşire ilişkisinin geliştirilmesi ve hemşirelik girişimlerinin gerçekleştirilmesi gerektiğinin önemi vurgulanmıştır. ${ }^{8,14,15,29,30 \quad \text { Araştırmada }}$ hemşirelerin çoğunluğunun manevi bakımda "hastalar için önemli olan manevi aktivitelerin ve inanışların desteklenmesi $(\% 68,6)$ "nin ve "manevi konularda konuşmak isteyen hastalara din görevlisi ile konuşmak isteyip istemediklerinin sorulması $(\% 50,8)$ "nın ve "Hastalar manevi desteğe sahip ise desteği sağlayacak kişilerin tedaviye dahil olmasinı isteyip istemediklerinin sorulması $(\% 50,7)$ 'nın hastalar için çoğu zaman uygun bir uygulama olduğunu belirtmişlerdir. Balboni ve ark. (2013) çalışmasında ise, hemşirelerin çoğunluğu hastaların manevi inanç ve uygulamalarının desteklenebileceğini (\%99), hastalarının manevi konularda konuşmak için din görevlisine yönlendirilebileceğini (\%98) ve manevi ya da dini destek sağlayabilecek kişilerin onların bakımına dahil edilip edilmeyeceğini sorulabileceğini belirtmişlerdir. Aynı araştırmada "Manevi duyguları yüksek hastaya dua etmesi için din görevlisi önerilmesi $(\% 5,7)$ " manevi bakım uygulamasına hemşirelerin \%50,7 sin bazen uygun bir uygulama olabileceğini belirtirken, \%23,9'u hastalar için hiç uygun bir uygulama olmadığını belirtmişlerdir. Ayrica, "Hasta birlikte dua edilmesini isterse doktor ya da hemşirenin hasta ile birlikte dua etmesi" manevi bakım uygulamasına hemşirelerin \%43,3'ü bazen uygun bir uygulama olabileceğini belirtirken, \%40,3'ü hastalar için hiç uygun bir uygulama olmadığını belirtmiştir. ${ }^{6}$ Hemşireler, hastalarının manevi gereksinimlerinin farkında olmali; hastalarına kendi, dini veya manevi düşüncelerinden etkilenmeden destekleyici manevi bakım sunabilmelidir. ${ }^{15,24,27}$ Kanser hastalarına bakım veren ekibin 24 saat hizmet veren üyesi olarak hemşirelerin manevi gereksinimler bilgi, beceri ve yaklaşımlarının profesyonel düzeyde olması beklenmektedir.

Hemşirelerin hastanın tedavi ve bakımında manevi bakımın gerekliliğini bildikleri halde uygulamada birtakım engeller ile karşılaşabilmektedir. ${ }^{1,15}$ Araştırmada hemşireler manevi bakımda karşılaşılan "yeterli zaman yokluğu $(\% 94,8)$ ", "hasta ile manevi konuların konuşulup tartışılabileceği özel mekanların yokluğu $(\% 89,5)$ " ve "manevi konularda eğitim eksikliği $(\% 83,6)$ " engellerinin oldukça önemli engeller olduğunu belirtmişlerdir. Balboni ve ark. çalışmasında, kanser hastalarına bakım veren hemşirelerin \%73'ü hastalara manevi bakım sağlayacak yeterli zaman olmamasını önemli bir engel olarak belirtmişlerdir. ${ }^{3}$ Ayrıca, hemşirelerin manevi bakım konusunda eğitim almasının, hastalarına manevi bakım hizmeti sunmalarında etkili olduğunu belirtmişlerdir. Literatürde hekim ve hemşirelerde yaşam sonu manevi bakım uygulamalarında karşılaşılan engelleri belirlemeyi amaçlayan çalışmalarda da, araştırmamıza benzer sonuçlar belirtilmiş, en s1k karşılaşılan engeller; yeterli zaman olmamas1 (\%71-66), manevin konuların konuşulacağı özel mekanların olmaması (\%74-58), manevi bakım konusunda eğitimlerinin olmaması (\%54-6) olarak belirtilmiştir. $^{7,26}$ Araştırmanın sonuçları literatür ile benzer bulgular içermekte, belirtilen engellere yönelik farkındalık oluşturması açısından önem taşımaktadır. Manevi bakım uygulamasında karşılaş1labilecek engelleri aşabilmek için, hemşirelik eğitiminde manevi bakım kavramına yönelik yeterli bilgi verilmesi, müfredat programlarının düzenlenmesi ve uygulamada kullanılabilecek stratejilerin geliştirilmesi önerilebilir. 


\section{SONUÇ VE ÖNERILLER}

Hemşireler, manevi bakımın sağlanmasında ekibin en önemli üyelerinden birisidir. $\mathrm{Bu}$ araştırmanın sonuçları, hemşirelerin kanser hastaları için manevi bakımın ve profesyonel manevi bakım uzmanlarının öneminin farkında olduklarını, manevi bakım konusunda yeterli bilgiye sahip olmadıklarını ancak manevi bakım konusunda eğitim almak istediklerini göstermektedir. Bununla birlikte, hemşireler kanser hastalarına uygun olabilecek manevi bakım uygulamaları olarak; kanser hastaları için önemli olan manevi aktivitelerin ve inanışların desteklenmesini, hastalara manevi konularda konuşmak için din görevlisi önerilmesini, manevi desteği olan hastaların destek sistemlerinin harekete geçirilmesini vurgulamışlardır. Hemşireler manevi bakım uygulamalarıyla ilgili karşılaşılan engeller olarak; yeterli zaman ve özel mekanların olmadığını, konuyla ilgili eğitimlerin yetersiz olduğunu belirtmişlerdir.

Hemşireler, bütüncül yaklaşım doğrultusunda hastalarına bakım hizmeti sunarken, hastaların manevi ihtiyaçlarının giderilmesine yönelik girişimleri hemşirelik bakımlarına entegre etmelidir. Bunu sağlamak için de manevi bakım ve maneviyat konularında yeterli bilgiye sahip olmaları gereklidir. Araştırma sonuçları doğrultusunda, özellikle kanser hastalarına bakım veren hemşirelerin mezuniyet sonrası eğitimler ile manevi bakım konusunda bilgi düzeylerinin iyileştirilmesi ve manevi bakımın hangi koşullar altında yapılması gerektiği ve hastaların manevi ihtiyaçlarının belirlenmesi ve bu ihtiyaçların azaltılmasına yönelik girişimlerin planlandığ oluşturulmalıdır. Ayrıca, manevi bakımın sadece teorik eğitim ile kalmaması, manevi bakım uygulamalarının hasta bakımına yansitilmasi, hastalarin talepleri doğrultusunda manevi bakım uygulamalarının sıklığının arttırılması önerilmektedir.
1. Puchalski, CM, Sbrana, A, Ferrell, B, Jafari, N, King, S, Balboni T, ve ark. (2019). "Interprofessional spiritual care in oncology: a literature review." ESMO open, 4 (1), 1-12.

2. Erişen, M, Karaca Sivrikaya, S. (2017). "Manevi bakım ve hemşirelik.” GÜSBD, 6 (3), 184-190.

3. Balboni, TA, Balboni, M, Enzinger, AC, Gallivan, K, Paulk, ME, Wright A. ve ark. (2013). "Provision of spiritual support to patients with advanced cancer by religious communities and associations with medical care at the end of life." JAMA Intern Med, 173 (12), 1109-17.

4. Pearce, MJ, Coan, AD, Herndon, JE, Koenig, HG, Abernethy, AP. (2012). "Unmet spiritual care needs impact emotional and spiritual well-being in advanced cancer patients." Support Care Cancer. 20 (10), 2269-76.

5. Balboni, T, Balboni, M, Paulk, ME, Phelps, A, Wright, A, Peteet, J, ve ark. (2011). "Support of cancer patients' spiritual needs and associations with medical care costs at the end of life." Cancer, 117 (23), 5383-91.

6. Bar-Sela, G, Schultz, MJ, Elshamy, K, Rassouli, M, BenArye, E, Doumit, M, Ozalp, G ve ark. (2019). "Human Development Index and its association with staff spiritual care provision: a Middle Eastern oncology study." Support Care Cancer, 27, 3601-10.

7. Bar-Sela, G, Schultz, MJ, Elshamy, K, Rassouli, M, Ben-Arye E, Doumit, M, ve ark. (2019). "Training for awareness of one's own spirituality: A key factor in overcoming barriers to the provision of spiritual care to advanced cancer patients by doctors and nurses." Palliat Support Care, 17 (3), 345-52.
8. O'brien, MR, Kinloch, K, Groves, KE, Jack, BA. (2019). "Meeting patients' spiritual needs during end-of-life care: A qualitative study of nurses' and healthcare professionals' perceptions of spiritual care training." J Clin Nurs, 28 (1-2), $182-189$.

9. Osman, H, Shrestha, S, Temin, S. (2018). "Palliative care in the global setting: ASCO Resource-Stratifed practice guideline." J Glob Oncol, 4, 1-24.

10. Ehman, J. (2018). "References to Spirituality, Religion, Beliefs, and Cultural Diversity in the Joint Commission's Comprehensive Accreditation Manual for Hospitals." http://www.uphs.upenn.edu/pastoral/resed/JCAHOrefs.pdf (Erişim tarihi:16.06.2020)

11. Balboni, TA, Vanderwerker, LC, Block, SD, Paulk, ME Lathan, CS, Peteet, JR, ve ark. (2007). "Religiousness and spiritual support among advanced cancer patients and associations with end-of-life treatment preferences and quality of life." J Clin Oncol, 25 (5), 555-60.

12. Thompson, GN, Chochinov, HM, Wilson, KG, McPherson, CJ, Chary, S, O'Shea, FM, ve ark. (2009). "Prognostic acceptance and the well-being of patients receiving palliative care for cancer." J Clin Oncol, 27 (34), 5757-62.

13. Tarakeshwar, N, Vanderwerker, LC, Paulk, E, Pearce, MJ, Kasl, SV, Prigerson, HG. (2006). "Religious coping is associated with the quality of life of patients with advanced cancer." J Palliat Med, 9 (3), 646-57.

14. Narayanasamy, A, Owens, J. (2001). "A critical incident study of nurses'responses to the spiritual needs of their." J Adv Nurs, 33 (4), 446-55. 
15. Carpenter, K, Girvin, L, Kitner, W, Ruth-Sahd, LA. (2008). "Spirituality: A dimension of holistic critical care nursing." Dimens Crit Care Nurs, 27 (1), 16-20.

16. Taylor, EJ, Mamier, I, Ricci-Allegra, P, Foith, J. (2017). "Self-reported frequency of nurse-provided spiritual care." Appl Nurs Res, 35, 30-35.

17. Phelps, AC, Lauderdale, KE, Alcorn, S, Dillinger, J, Balboni, MT, Van Wert, M, ve ark. (2012). "Addressing spirituality within the care of patients at the end of life: perspectives of patients with advanced cancer, oncologists, and oncology nurses." J Clin Oncol, 30 (20), 2538-44.

18. Sağlık Bakanlığı. (2015). "Hastanelerde Manevi Destek Sunmaya Yönelik İşbirliği https://www.saglik.gov.tr/TR,558/hastanelerde-manevidestek-sunmaya-yonelik-isbirligi-protokolu-imzalandi.html (Erișim tarihi:16.06.2020)

19. Sağlık Bakanlığı Sakarya İl Sağlık Müdürlüğü. (2019). "Hastanelerde Manevi Destek ve Rehberlik Hizmeti." https://sakaryaeah.saglik.gov.tr/TR,20365/hastanelerdemanevi-destek-ve-rehberlik-hizmeti.html (Erişim tarihi:16.06.2020)

20. National Consensus Project. (2018). "Clinical Practice Guidelines for Quality Palliative Care." https://www.nationalcoalitionhpc.org/wpcontent/uploads/2018/10/NCHPC-

NCPGuidelines_4thED_web_FINAL.pdf (Erişim tarihi: 16.06 .2020$)$

21. Institute for Clinical Systems Improvement. (2019). "Health Care Guideline: Palliative Care for Adults." https://www.icsi.org/wp-

content/uploads/2019/08/PalliativeCare082219_publiccomment_v2.pdf (Erişim tarihi:16.06.2020)

22. International Council of Nurses. (2002). "Nursing Definitions" https://www.icn.ch/nursing-policy/nursingdefinitions\#: :text=ICN\%2C\%202002),care\%20and\%20other \%20community\%20settings. (Erişim tarihi:10.08.2020)

23. Çelik İnce, S, Utaş Akhan, L. (2016). "Öğrenci hemşirelerim maneviyat ve manevi bakıma ilişkin algıları”. HEAD, 13 (3), 202-08.

24. Sawatzky, R, Pesut, B, Sawatzky, R, Pesut, B. (2005). Attributes of spiritual care in nursing practice. J Holist Nurs, 23 (1), 19-33.

25. Kavas, E, Kavas, N. (2014). "Spiritual support perception (MDA) scale: development, validity and reliability." Turkish Studies, 9 (2), 905-15.

26. Balboni, MJ, Sullivan, A, Enzinger, AC, Epstein-Peterson, ZD, Tseng, YD, Mitchell, C, ve ark. (2014). "Nurse and physician barriers to spiritual care provision at the end of life." J Pain Symptom Manage, 48, 400-10.

27. Memaryan, N, Jolfaei, AG, Ghaempanah, Z, Shirvani, A, Vand, HD, Ghahari, S, ve ark. (2016). "Spiritual care for cancer patients in Iran." Asian Pac J Cancer Prev, 17 (9), 4289-94.

28. Sülü Uğurlu, E. (2014). "Hemşirelikte manevi bakımın uygulanması." Acıbadem Üniversitesi Sağlık Bilimleri Dergisi, 5 (3), 187-91.

29. Mamier, I, Taylor, EJ, Winslow, BW. (2019). "Nurse spiritual care: prevalence and correlates." West J Nurs Res, 41 (4), $537-54$.

30. Taylor, EJ, Mamier, I, Ricci-Allegra, P, Foith, J. (2017). "Selfreported frequency of nurse-provided spiritual care." Appl Nurs Res, 35, 30-5.

31. Lovanio, K, Wallace, M. (2007). "Promoting spiritual knowledge and attitudes." Holist Nurs Pract, 21 (1), 42-7.
32. Mcsherry, W, Jamieson, S. (2013). "The qualitative findings from an online survey investigating nurses' perceptions of spirituality and spiritual care." J Clin Nurs, 22 (21-22), 317082.

33. Selby, D, Seccaraccia, D, Huth, J, Kurrpa, K, Fitch, M. (2016). "A qualitative analysis of a healthcare professional's understanding and approach to management of spiritual distress in an acute care setting." J Palliat Med, 19 (11), 1197 204 